\title{
Children's Books on WWII within the Collective Memory of the Ukrainian Diaspora
}

\author{
Maryna Vardanian ${ }^{1, *}$ \\ ${ }^{1}$ Kryvyi Rih State Pedagogical University, Ukraine \\ *Corresponding author.Email: maryna.vardanian@gmail.com
}

\begin{abstract}
The article deals with the issue of World War II (WWII) in the books for children by the Ukrainian Diaspora of the twentieth century. Along with other works on WWII theme in world literature, books by Ukrainian Diasporic writers for children and young adults (YA) such as Bodnarchuk's Kladka (Small Bridge), Bryzghun-Shanta's Moia Taiemnytsia (My Secret), Dmytrenko's Mykhailyk, and Tsehelska's Petruseva Povist (Petrusev's Story) depict WWII and its consequences for Ukrainians. I claim that Ukrainian works on WWII theme are based on the collective memory theory referred to by Maurice Halbwachs and Barbara Shatska. My position is that WWII theme in children's literature is centered closely on the collective memory of the Ukrainian Diaspora. In reference to Halbwachs' interpretation of collective memory as a way of group identity, awareness of the general past, significant values, and symbols, I consider collective memory in children's literature as a necessary way to deal with the traumatic experience of the Ukrainian Diaspora. My analysis then focuses on the investigation of how these concepts are implemented in children's books.
\end{abstract}

Keywords: children's books, WWII, collective memory, Ukrainian Diaspora.

\section{INTRODUCTION}

For centuries, Ukraine fought for its statehood and independence. Having achieved that in the twentieth century, our compatriots felt the necessity to change their vision of some phenomena and stereotypes acknowledged for years and firmly rooted in the people's consciousness. Among the urgent social and political facts which are being rethought is World War II. The reviewing of this event by politicians, history scholars, and ordinary Ukrainians is of significance for several reasons. Firstly, independent Ukrainian society seeks to rid itself of the ideological clichés of the Soviet epoch, which represents World War II as the Great Patriotic War. Secondly, Ukrainians are clarifying to the world community their position in the war, which was, indeed, a struggle for independence. Ukrainian history expresses these opposing viewpoints in the understanding of World War II. Considering this, one should point out that this perception of the war has over time penetrated other spheres of Ukrainian society, specifically, to cinematography, theater, and literature.

A contemporary set of war writings for adults shows this, and we see it also in children's literature.
It is necessary to note that Ukrainian war literature for children in the twentieth century developed in two directions, namely, the Soviet and the Diasporic. The two branches of Ukrainian literature (UkrainianSoviet and Ukrainian-Diasporic) show different kinds of collective memory. Ukrainian researchers explore the historical narratives of World War II interpretation because the Ukrainian nation needs to rethink its own colonial past, to consolidate several kinds of collective memory, and to form a united national memory. Hence, the war theme is the subject matter of various research papers. Of these works, the thesis Military Paradigm in the Literature of Socialist Realism (Evolution, Functions, and Aberrations) by Iryna Zakharchuk [11] will be examined first. Some of its aspects in children's literature were previously considered in my monograph The Self - the Other in the children's literature of the Ukrainian Diaspora: national sphere of concepts, imagological models [10].

As was mentioned, the dominant Soviet narrative of World War II for both adults and children represented it as the Great Patriotic War. The world political and literary community has become more aware of this fact. The portrayal of World War II in 
children's Diasporic literature at the time of independence has not been thoroughly investigated, and the problem of the collective memory of Diasporic writings for the younger generation requires deep and detailed research. I present a point of view in opposition to the Soviet version. Thus, the purpose of my paper is to consider the implementation of the collective war memory in books for children and YA produced by Ukrainian emigrant writers. This goal is relevant due to the following reasons.

Firstly, it is necessary for the youth to discover such historical narratives because the new generation of Ukrainians is growing up after the breakup of the Soviet Union as well as during the Russian aggression against Eastern Ukraine after the annexation of Crimea in 2014. Because of this, young Ukrainians are keenly conscious that a war is neither a romantic nor heroic event, but one that brings destruction, fear, and death. As well, this younger generation of Ukrainians grasps the various historical narratives and memories about World War II. These texts may be of interest to the world community, too.

Secondly, discovering their own Ukrainian experience through the historical narratives of short stories for children gives voice to Ukrainian literature. Unfortunately, the world community still often considers Ukrainian literature (and, in fact, the history of Ukraine and its territory) as Soviet-Russian. Postcolonial studies explain this phenomenon through the centrism / marginalization, the Self / the Other issues, etc. My research is not aimed at investigating these cultural and literary items, instead, its intent is to induce dialogue on understanding the war theme in works for children and YA, based on the hermeneutic circle category; in this research, there is also the goal to create a set of heterogeneous historical narratives in reviewing the war themes in short stories belonging to various national literatures for children and YA.

Thirdly, World War II discourse should be studied comprehensively through the category of memory. In this way, scholars establish a scientific dialogue between opponents in which everyone has the right to express his/her own opinion which is presented as the collective memory of his/her national literature.

Therefore, this essay has the following tasks:

(1) to describe the military experience of Ukrainian emigrants which stimulated the birth of the collective memory of the war and occupation, presented in books for children and YA;

(2) to determine the images of 'the dangerous' and 'the suffering' in the works by I. Bodnarchuk,
L. Poltava, L. Bryzghun-Shanta, M. Dmytrenko,

B. Fedchuk, and O. Tsehelska;

(3) to identify models of discovering the Other based on E. Levinas's theory of responsibility for the Other in his work On Thinking-of-the-Other.

\section{MILITARY EXPERIENCE OF UKRAINIAN EMIGRANTS AND COLLECTIVE MEMORY}

The conceptual base of my research about Ukrainian emigrants' collective memory fully harmonizes with the approaches suggested in monographs by philosopher Maurice Halbwachs and sociologist Barbara Shatska. These scholars represent the notion and the specific character of collective memory.

In her book Past - Memory - Myth, Shatska defined collective memory as "perceptions of the community about its past, their inhabitants, events that occurred in this past, and ways to perpetuate and transmit the knowledge that is considered to be obligatory for a member of that community" [8].

Yet, in the last century, Maurice Halbwachs noticed that one of the key capacities of a phenomenon such as collective memory is that it "...helps to create the group identity, in particular, awareness of the general past, significant values, and symbols" [1].

In terms of Ukrainian Diasporic literature, the notion of collective memory is rather wide. It is explained by the fact that a whole generation of Ukrainians was outside their native territory in the twentieth century. The collective memory and, accordingly, military experience of Ukrainian emigrants comprise the reminiscences of the lost childhood or youth, loss of relatives, the defeat in the war, the occupation of Ukraine, the destruction, the imprisonments, and forced emigration. Similar personal stories formed a collection of memories written by Ukrainian emigrants of the twentieth century.

\subsection{The thematic groups of Ukrainian emigrant memories of the twentieth century}

The memory heritage of Ukrainian emigrants is very rich. It made a great contribution to the development of the national culture and demonstrates the collective memory of Ukrainians who left their country during or after the war. One can single out the following thematic groups of memories:

(1) the different stages of Struggles for Liberty and the Ukrainian Revolution in 1917 - Diary of the 
Prisoner by Oleksa Kobets (Munich, 1959), Children of War by M. Sharyk (Winnipeg, 1955-1956), Ukrainian Tragedy by M. Doroshenko (New York, 1980), etc.;

(2) the Holodomor - the Ukrainian Famine of 1932-33 - Witness: Memoirs of the Famine of 1933 in Ukraine by Pavlo Makohon (Toronto, 1983), For All about Everything by Klavdiia Folts (Sydney, 1988), and etc.;

(3) memories about World War II - In the Forests near Viazma by Dmytro Chub (Melbourne, 1983), and The Second World War Reminiscences of an Ordinary Man by V. Barahura (New York, 1991);

(4) the imprisonment of Displaced Persons (D. P.) - Planet of DP's by Ulas Samchuk (Winnipeg, 1979), On the Second Stage by V. Hotskyi (London, 1990), Into Auschwitz, for Ukraine by S. Petelytckyi (Kyiv, 2000), Album of a Political Prisoner by Paladii Osynka (Munich, 1956), In the Nazi Mills of Death by P. Mirchuk (New York-London, 1957), etc.;

(5) works about repressions organized by the Soviet authorities - 595 Days a Soviet Prisoner by I. Nimchuk (Toronto, 1950), Pull off a Mask from the Soviet Union by A. Vysochenko (Buenos Aires, 1951), The Moscow Hell by I. Kiiko (Toronto, 1988), etc.;

(6) writings about disastrous wanderings of Ukrainian emigrants - On Foreign Soil by M. Kuzmovych-Holovinska (Toronto, 1977), The Journey of My Life by M. Chartoryiskyi (New York, 1974), etc.

The above-mentioned literary works are valuable, as they originated from the collective memory of Ukrainian writers who were witnesses of and participants in these tragic events. The historical authenticity in these writings was very often supported by factual material, photos, and documents, the main purpose of which was to expose the Soviet totalitarian regime, contrasting it with the Ukrainian cultural identity. Regardless of the genre and time of issue, all these living histories are united by the concept of the war because it divided the lives of Ukrainian families and the whole nation into pre-war and post-war periods.

\subsection{The main military narratives in the writings of Ukrainian emigrants}

In the literature of Ukrainian writers for children and YA, there are three dominant themes of military narratives.
The first theme is about Ukrainians joining different armed groups and the Allied army during World War II. This theme is very sensitive. Before the war, the territory of Ukraine was divided among different countries. Even after the Ukrainian revolution in 1917, when Ukraine united its lands and declared its independence in 1921, it failed to establish itself due to the external aggression of neighboring countries. But the idea of restoring Ukraine's independence and statehood has always inspired Ukrainians in the struggle. For modern Ukraine, this theme is the most difficult because it is both a great catastrophe and tragedy for Ukrainians and an impetus to rebellion.

In this respect, the words of the Ukrainian emigrant, political scientist, and writer Paladii Osynka (known as Petro Balei) about the participation of Ukrainians in World War II, which he expressed in his picture book Album of a Political Prisoner in 1946, are still relevant today.

Deep rooted opposition to the Soviet propaganda is one of the key points of the Ukrainian Diaspora and can be seen to this day. In this way, Canadian Ukrainians consciously aimed to destroy the myth about the overwhelming victory of the Russian SFSR (the Russian Soviet Federative Socialist Republic) in World War II. M. Marunchak is not only a witness of those events, but also a researcher of Ukrainian history and emigration. He describes Ukrainian efforts in World War II in his work History of Ukrainian Canada and shows that Ukrainians joined the Canadian army as volunteers, they were in the underground Ukrainian army, and millions of Ukrainians also served in the Red Army during World War II. "In total, it was a huge contribution of the Ukrainian people to the military efforts of World War II", states Marunchak [4].

The second theme describes the occupation of Ukraine first by Nazi Germany and then by the Soviet Union. In works by the Ukrainian Diaspora, Nazi Germany and the Soviet Union are empires that viewed Ukraine as a colony. A clear example of this is the article The Invader Changes the Invader by Les Oleksander published in The Winged Ones (1970), a monthly magazine for Ukrainian youth.

The author's comment for the picture below is revealing: "What does this picture taken in 1944 in a Ukrainian town in Galicia tell us? We see Soviet tanks. The streets are empty. Residents are hiding because they hated German fascists and hate the new invaders from Moscow. On the ground, we can see German signs for Lemberg instead of the Ukrainian name Lviv. 
The new invader of Ukraine has already established his own signs in Russian - Lvov" [5].

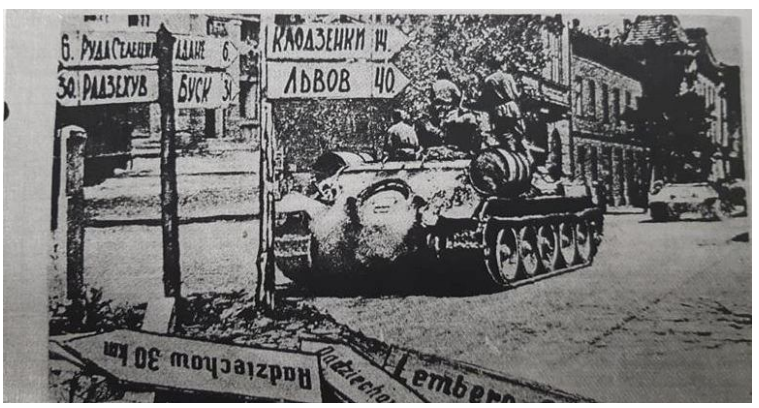

Figure 1. A picture from the article The Invader Changes the Invader by Les Oleksander

The third theme is about the forced emigration during World War II. For Ukrainians, World War II is the most traumatic period. It is well-known that in addition to millions of lives lost, many people were forced to emigrate. There were three groups of Ukrainian emigrants. During World War II, more than 2 million young Ukrainians and families were unwillingly removed to Germany for labor ( $1^{\text {st }}$ group); other people were in camps for Displaced Persons $\left(2^{\text {nd }}\right.$ group); yet more Ukrainians fled repression by the Soviet authorities for their progressive national views ( $3^{\text {rd }}$ group).

The most prominent example of the third theme is the book by Ukrainian writer and publicist Ivan Bahrianyi Why I Am Not Going Back to the Soviet Union published in 1946. This book is devoted to exposing the Soviet regime and its terrible nature, experienced by the author himself. Being published earlier than the works by Alexander Solzhenitsyn, Bahrianyi's work has evoked a great resonance in the post-war world. So, rooted firmly in personal experience and views, memories and other works by the Ukrainian Diaspora formed the collective memory of Ukrainians in exile. Writers tried to preserve this memory for future generations of young Ukrainians.

\section{THE WAR IN CHILDREN'S BOOKS}

Today young Ukrainians have a variety of writings on military themes at their disposal. As was mentioned before, presently the development of military discourse is connected largely with the current Russian aggression against Ukraine. Works for young Ukrainians can be classified into the following groups:

The first group of books contains writings by authors who survived World War II. These writers are named as 'the children of the war generation'. Ukrainian schoolchildren can read about the war and the post-war period in works produced by authors such as V. Blyznets, H. Tiutiunnyk, Y. Hutsalo, and V. Rutkivskyi. I include Ukrainian Diaspora books that were banned during the Soviet era in this group. These books will be spoken about in greater detail later in this essay.

The second group of texts includes the books of contemporary writers about the modern war and Russian aggression against Ukraine. These include works by I. Malkovych, K. Lukashchuk.

The third group consists of translations of children's books about the war by non-Ukrainian writers. Young Ukrainians can read books such as All the Light We Cannot See by Antony Doerr, The Boy in the Striped Pajamas by John Boyne, The Whispering Town by Jennifer Elvgren, Ark of Time by Marcin Szczygielski, and The Book Thief by Markus Zusak. Despite differences in time, place, and language, these works are united by this main concept - the view that war is suffering, misery, and ruin.

\subsection{The models of fictional interpretation of the war in Ukrainian literature of the twentieth century}

Ukrainian scholars, particularly I. Zakharchuk [11], A. Hurbanska [2], V. Kharkhun [3], I. Rusnak [7], unanimously define three controversial models of fictional interpretation of the war in Ukrainian literature of the twentieth century. In the books for children, the following war models are usually distinguished: (1) the Soviet-military model (wellknown in the world literary discourse); (2) the traumatic model consists of works by the UkrainianSoviet writers named as 'the children of the war generation'; (3) Ukrainian-nationalist model.

The first two models (the Soviet-military model and traumatic model) embody opposite experiences and collective flashbacks of the war in UkrainianSoviet literature. I. Zakharchuk called it the ceremonial, paradelike, and heroic interpretation of the war. Here, the characters of the writings are traditionally divided into heroes and enemies. In this respect, one must mention Praporonostsi (Flag Bearers) by O. Honchar which distinctly implements the official narrative of the Ukrainian-Soviet war experience. According to Zakharchuk, this novel formed both colonial and imperial narratives, i.e., the Soviet military presence outside of the USSR was interpreted by the great author as necessary and inevitable for the spiritual salvation of Europe [11].

In general, the writings for children and YA were also filled with heroic and romantic motifs. Their authors stuck to the official narrative of the war as the 
main concepts were the great victory over the German fascists, the courageous struggle of the heroes, and panegyrics on the Soviet Union as a common motherland. The official war narratives were actualized in the works for children and YA by Ukrainian-Soviet writers such as O. Kopylenko, O. Donchenko, O. Ivanenko, and P. Panch.

The Ukrainian-Soviet writers named as 'the children of the war generation' however, changed the official war narratives in Ukrainian literature of the 60's because, as Zakharchuk emphasizes, “... the children's memories of the war were fundamentally different from their parents' experience" [11]. Therefore, one can say that the reminiscences of children influenced the birth of changes of war interpretation in fiction. Specifically, V. Blyznets, H. Tiutiunnyk, and Y. Hutsalo transformed the very approach towards the war description: they substituted heroic narratives with traumatic and tragic visions of the war in their works for children and YA, in which special attention was drawn to the images of children and mothers, emphasizes A. Hurbanska [2].

The third model of the war is based on military experience of Ukrainian emigrants; thus, the next part of this essay highlights the Ukrainian-nationalist war model, which is revealed in the works by the most famous Ukrainian Diasporic writers.

\subsection{The Ukrainian-nationalist war model in the writings for children}

In children's books by the Ukrainian Diaspora, one can trace the viewpoint similar to the contemporary Ukrainian interpretation of the war as both a personal and national drama and a struggle for independence. Among the numerous types of texts for children, it is possible to name two main groups: (1) belletristic (including short stories and poems), and (2) essays and memories published in the patriotic magazines for Ukrainian youth such as The Winged Ones. Here, children are the main characters of writings by authors such as I. Bodnarchuk, L. Poltava, O. Tsehelska, and L. Bryzghun-Shanta.

The concept of a child in their works can be characterized by the following features: he / she is a witness or participant of World War II; he / she may be an orphan, a refugee, or a fighter; a child struggles for his / her destiny, purpose, and identity in both Europe and occupied Ukraine. These writers describe children on the edge between life and death in military [10]. One also should keep in mind that these writings are not about heroic war events, but they are about human losses and victims.
There are two thematic groups of works about the war for young Ukrainians. The first one is about children who were forced to leave Ukraine during World War II. In particular, O. Tsehelska in her book Petruseva Povist (Petrusev's Story) tells about the deportation of a Ukrainian family to Germany for forced labor. L. Bryzghun-Shanta in her collection Moia Taiemnytsia (My Secret) and I. Bodnarchuk in his collection Kladka (Small Bridge) raise the problems of the Ukrainian patriots' persecution by the Soviet authorities and describe the scope of the great emigration in wartime.

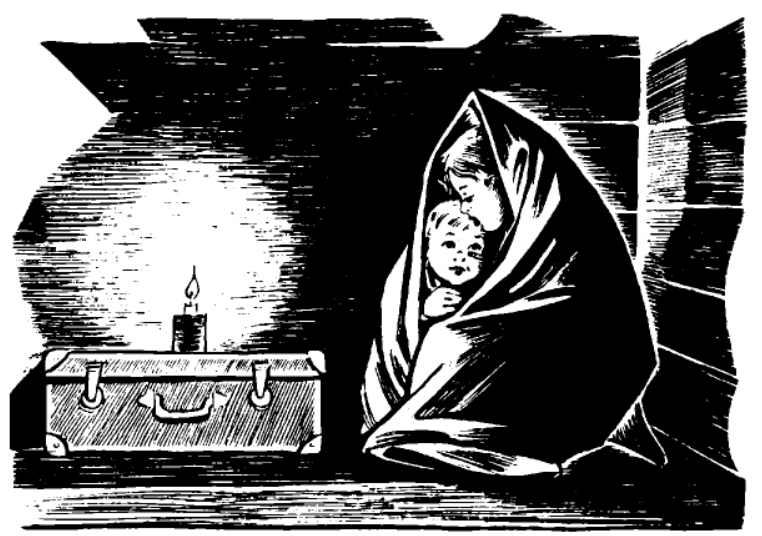

Figure 2. Pictures from Bodnarchuk's collection Kladka about the children's fate during WWII

The second thematic group of writings is about the collective image of a scout who fought for Ukraine in the underground army, namely the Ukrainian Insurgent Army. In the collective memory of the Ukrainian Diaspora, this underground army is a symbol of the struggle for independence of Ukraine against Nazi Germany and the Soviet authorities.

The collective reminiscences of this nature include Povstanets Yura (Fighter Yura) by V. Barahura, Ivaseva Shapka (Ivasev's Hat) by I. Bodnarchuk, Mykhailyk by M. Dmytrenko, and Pershyi Zakon Druzhby (The First Friendship Law) by L. Poltava. Particularly, in the book Mykhailyk (which has been published 7 times since 1949; in 1993 the print run amounted to 200,000 books), M. Dmytrenko aims to raise the problem of memory and historical truth of the Ukrainian liberation struggle.

Generally, the works by the Ukrainian Diaspora writers contain similar ideas, namely, the struggle for freedom of Ukraine against external enemies. The writers also portray the characters of insurgents and commanders as defenders of their own land. They focus on the civilians' support and their attitude towards the underground army, so they identify the insurgents as "our boys" and "our army". In addition, 
the authors not only describe the self-sacrifice of the underground army, but they also call for remembrance of the insurgents who died for Ukraine.

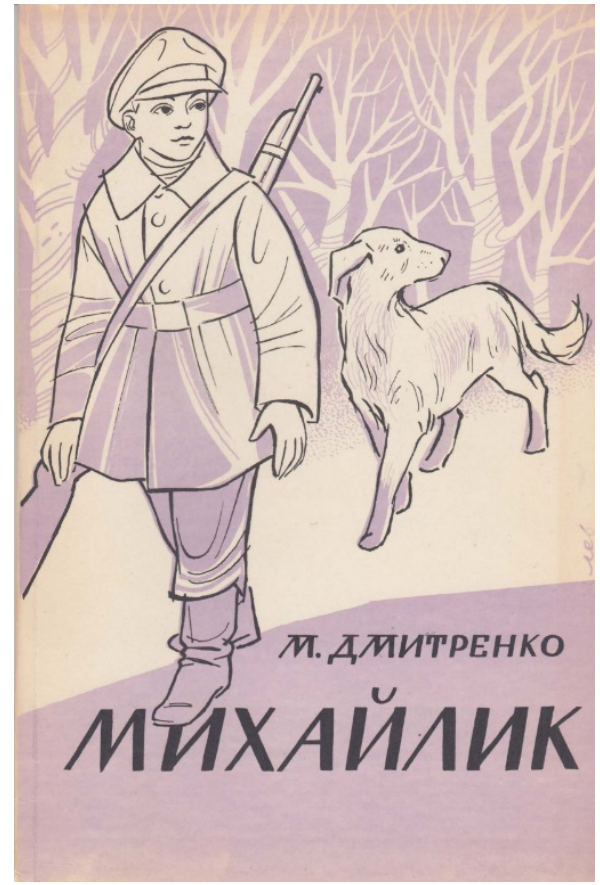

Figure 3. A cover of the bestseller Mykhailyk by Mariia Dmytrenko

\subsection{The image of Ukraine in the books for youth about the war}

Both thematic groups of the books about the war demonstrate the image of Ukraine in the past, present, and future. The image of Ukraine in the past appears as memories about the prosperous and rich Motherland. For instance, in I. Bodnarchuk's short story U Novii Hoverli (New Hoverla) children who were forced to leave Ukraine are going to search for the homeland, described by their mother.

The image of Ukraine in the present is the allegory of the mother's death. The writers describe Ukraine not as a strong state, obtaining its statehood in Kyivan Rus, but as a country fighting for its independence and preservation of its national identity. Nostalgia and sadness are the main motifs of the book Petruseva Povist (Petrusev's story) by O. Tsehelska. The author says: "Already we do not have the motherland, no native land. We are homeless, without land and roof" [9]. Also, the collective memory of the Ukrainian Diaspora describes Ukraine as the mother in grief, conveying hopelessness and horror. The book cover of the memoirs On Foreign Soil by M. KuzmovychHolovinska reflects this idea.
The image of Ukraine in the future is connected with the dream of returning to the motherland. The war in these writings is associated with sufferings and struggle in which there are no winners. Diasporic writers intended to pass their own experience on to the future Ukrainian children who would preserve the collective memory about the war, its heroes, symbols, and genuine human values.

Because of this, the writers give pieces of advice to their young descendants in different ways. For example, a family medallion given by parents to their children is the central image in the collection Moia Taiemnytsia (My Secret) by L. Bryzghun-Shanta. With the help of this authentic detail penetrating each poetic component of the story, the author expresses the idea of generation change. In this way, the youth preserve the Ukrainian national identity.

L. Poltava also appeals to children to expand and multiply the ancestors' deeds in his writing Liudyna, shcho z Neba Vpala (The Man who Fell from the Sky). The main character Vasylko becomes a well-known Canadian journalist and "he writes about Ukraine and its struggle for freedom" [6].

\subsection{The models of reception of the other}

In this research, I suggest two types of discovering the Other in the war books for children by Ukrainian Diasporic writers. The first one describes alienation and hostility, displaying xenophobia and imperial ambitions; the other model deals with communication, tolerance and support as values of multicultural coexistence.

\subsubsection{The other as dangerous}

The types of images in terms of 'the dangerous' are related to the category of the Alien that implies the enemy. They are represented by the empires and invaders who perceived Ukraine as a colony. The attributes of 'the dangerous' include the images of dungeons, darkness, burning ground, ruins, falling bombs, human sobs, torments, and death. The hostility is revealed through the images of the invaders.

Within the notion of 'the dangerous', in their works the writers consider several types of intolerance and rejection of another culture: an occupation, violence, executions, extermination of the village, forced labor, and hunger.

Children are depicted as witnesses of the war in writings by L. Bryzghun-Shanta, B. Fedchuk, I. Bodnarchuk, and L. Poltava. But 'the other' invaders are described as caustic and cruel persons, 
bringing destruction and death to Ukrainian lands, destroying the identity of Ukrainians, their culture and native language. More than that, both German fascists and the Soviet authorities murdered Ukrainians physically and morally, and therefore these images are reproduced negatively with the usage of their native language (Russian or German) and description of their military uniform.
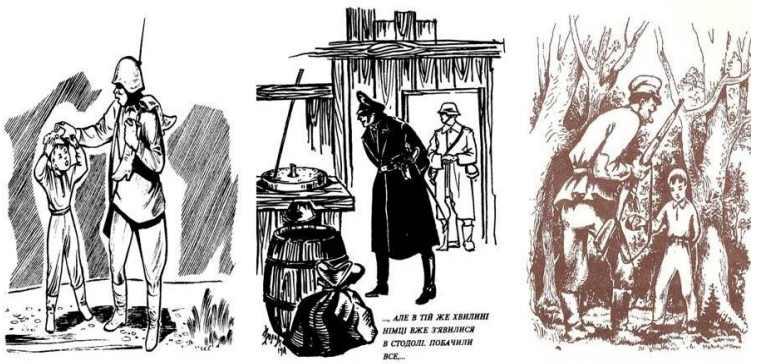

Figure 4. The images of the Red Army soldiers and German fascists (on the left - Bodnarchuk's Ivasev's Hat, in the middle - Fedchuk's Hania, on the right Poltava's The First Friendship Law

B. Fedchuk addresses the historical facts in his short story Hania. He describes the horrible destruction of entire villages by Nazi invaders and deportation to Germany for forced labor. The author simultaneously argues that the Soviet authorities exterminated Ukrainians and made them suffer from artificial famine.

\subsubsection{The other as closely related}

Nevertheless, Ukrainian writers declare the idea of an acceptable neighborhood of different cultural communities. In this chapter, I describe the second model through several key concepts: depiction of the Allies, fighting against evil during World Word II, assistance to Ukrainians in emigration, and reconsidering post-war values.

L. Poltava and O. Tsehelska proclaim unity, support, and mutual assistance in their writings, and therefore do not describe the tribunal for the enemy who started the war. Instead, they call for unity to resist evil and put an end to the war. In their works, the Canadian, American, and British planes, as angels, save the world from evil. So, the world is subjected to symbolic cleanup and redemption, and it believes that a war will never happen again.

Like his colleagues, I. Bodnarchuk in his story $V$ Bratyslavi (In Bratislava) also argues that tolerance and support are extremely significant values of the multicultural existence. This short story takes place in the Slovak Republic, as the main characters Andriiko, his mother, and sister have immigrated to this country. On the one hand, the author represents the difficult conditions of Ukrainians' life (unemployment, hunger, arrests, and illness), but, on the other hand, he reveals how the Slovak boys act towards the Ukrainian refugee family: they help Ukrainians in their need despite the risk and danger for their own lives.

A little boy Petrus is the narrator of Petruseva Povist (Petrusev's story) by O. Tsehelska. He tells about the deportation of a Ukrainian family to Germany for forced labor. In this writing, the author tries to raise the urgent moral and social problems of that time: the acceptance of the Other, the relationship between a stranger and a refugee, and the coexistence of different cultures where some of those involved were outside their own homelands.

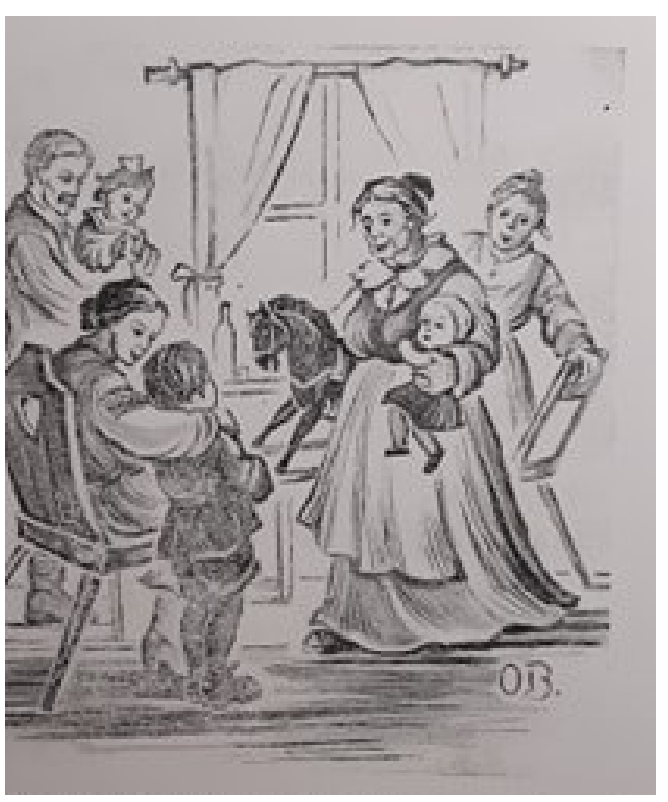

Figure 5. A picture of Petruseva Povist (Petrusev's story) by $\mathrm{O}$. Tsehelska. The families of Ukrainians and Germans are together after the war

Key moments in the short story are meetings between Petrus' family and the German Webers. It is interesting that $\mathrm{O}$. Tsehelska depicts Frau and Herr Weber as unfriendly and cruel at the first meeting, during the war. They treat the family of Ukrainians with contempt, force them to work hard, and their children cannot even get milk. The second meeting takes place after the war, and we see communication and mutual acceptance by both families. The writer assumes that the war had divided the world, but it had also united it. Taking part in the war changed everyone, and their moral values, have also, fortunately, changed. 


\section{CONCLUSION}

Children have always been participants in or witnesses of the tragic events of history and this is reflected in literatures.

1. The works for youth by Ukrainian Diasporic writers reveal the sacred character of their collective memory. These stories are based on the collective memories such as the occupations of Ukraine during and after World War II, forced labor, and emigration, the Ukrainian liberation movement against both Nazi Germany and the Soviet authorities, and the Ukrainians joining the Allied Armies. These issues are seen through the child characters. According to the Ukrainian Diaspora writers, works for children containing the different types of collective memories serve to preserve the national identity of Ukrainians who have a glorious history of their struggle for the independence of the Motherland.

2. At the same time, the Ukrainian Diaspora fought to represent the Ukrainian war experience, the subsequent consequences, and their impact on the fate of Ukrainian children who suffered no less from World War II than from physical and mental violence. In the Ukrainian Diaspora's opinion, the occupation of Ukraine by Nazi Germany was replaced by the repression of the people by the Soviet authorities in the war and the post-war time.

3. Having researched many children's stories of Ukrainian Diasporic war writings, the author of this article came to some conclusions. There are six representative thematic groups of memories produced by Ukrainian writers abroad; there are three important themes suitable for the military narrative in the writings of our compatriots in the Diaspora.

4. War literature by Ukrainian writers also has a specific character, as it consists of three groups, and fictional interpretation of the war theme in the literature of the last century can be classified into three models, in particularly the Soviet-military model, traumatic model, and Ukrainian-nationalist model. The third model is based on military experience of Ukrainian emigration; thus, it is revealed in the works by the most famous Ukrainian emigrant writers such as L. Poltava, B. Fedchuk, I. Bodnarchuk, O. Tsehelska, M. Dmytrenko, and L. BryzghunShanta. In these writings, I compare two models of reception of the Other defined as dangerous and as closely related. Thus, I consider that such models can be a qualitative approach in the exploring of the children's war discourse in Ukrainian Diasporic writings as well as in other works on military issues.

\section{REFERENCES}

[1] M. Halbwachs, Mary Douglas (introduction), The Collective Memory, Harper Colophon Books, New York, 1980.

[2] A.I. Hurbanska, Viktor Blyznets: literaturnyi portret (Viktor Blyznets: a Vignette), Kyiv, 1998.

[3] V. Kharkhun, Sotsrealistychnyi kanon v ukrainskii literaturi: geneza, rozvytok, modyfikatsii (Socialist Realistic Canon in the Ukrainian Literature: Genesis, Development, Modifications), Hydromax LLC, Nizhyn, 2009.

[4] M. Marunchak, Istoriia ukraintsiv Kanady (History of Ukrainian Canada), v. II, Ukrainian Free Academy in Canada Publisher, Winnipeg, 1991.

[5] L. Oleksander, The Invader Changes the Invader, The Winged Ones 8 (1970) 17.

[6] L. Poltava, The Little Bell-Ringer from Konotip, Our Children, Pbl., Toronto - New York, 1969.

[7] I.Y. Rusnak, "Ia buv povnyi Ukrainoiu...": khudozhnia istoriosofiia Ulasa Samchuka ("I was full of Ukraine...": Artistic Historiosophy of Ulas Samchuk), State Enterprise DKF, Vinnytsia, 2005.

[8] B. Shatska, Mynule - pamiat - mit (Past Memory - Myth), Books - XXI, Chernivtsi, 2011.

[9] O. Tsehelska, Petruseva povist (Petrus's Story), Our Children, Pbl., 1950.

[10] M. Vardanian, Svii - Chuzhyi v ukrainskii diaspornii literaturi dlia ditei ta yunatstva natsionalna kontseptosfera imaholohichni modeli (The Self - the Other in the Children's Literature of the Ukrainian Diaspora: National Sphere of Concepts, Imagological Models), Dionat, Kryvyi Rih, 2018.

[11] I. Zakharchuk, Militarna paradyhma literatury sotsialistychnoho realizmu (evoliutsiia, funktsii, aberatsii) (Military Paradigm in the Literature of Socialist Realism (Evolution, Functions, and Aberrations)), ScD Thesis Abstract, Kyiv, 2010. 